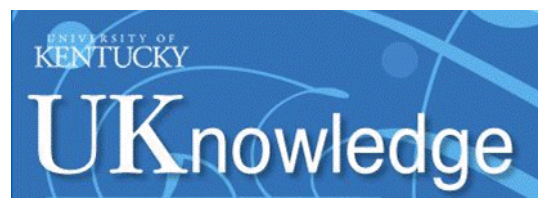

Kentucky Journal of Equine, Agriculture, \& Natural Resources Law

\title{
Towards the Heart of the Sport: A Sporting Perspective on Abraham \& Veneklasen Joint Venture v. American Quarter Horse Association
}

Samuel D. Hinkle

Stoll Keenon Ogden

Maria Gall

Stoll Keenon Ogden

Follow this and additional works at: https://uknowledge.uky.edu/kjeanrl

Part of the Animal Law Commons, and the Antitrust and Trade Regulation Commons

Right click to open a feedback form in a new tab to let us know how this document benefits you.

\section{Recommended Citation}

Hinkle, Samuel D. and Gall, Maria (2014) "Towards the Heart of the Sport: A Sporting Perspective on Abraham \& Veneklasen Joint Venture v. American Quarter Horse Association," Kentucky Journal of Equine, Agriculture, \& Natural Resources Law. Vol. 7: Iss. 1, Article 3.

Available at: https://uknowledge.uky.edu/kjeanrl/vol7/iss1/3

This Article is brought to you for free and open access by the Law Journals at UKnowledge. It has been accepted for inclusion in Kentucky Journal of Equine, Agriculture, \& Natural Resources Law by an authorized editor of UKnowledge. For more information, please contact UKnowledge@lsv.uky.edu. 
TOWARDS THE HEART OF THE SPORT:

\section{A SPORTINg PERSPECTIVE on ABRAHAM E VENEKLASEN \\ JOINT VENTURE V. AMERICAN QUARTER HORSE \\ ASSOCLATION}

\section{Samuel D. Hinkle and Maria Gall}

\section{INTRODUCTION}

ules defining the characteristics of horses that may be registered Wwith a particular breed organization are essential to defining not only the breed to which the organization is devoted but also the collateral activities of the organization necessary to promote the breed, such as show competitions, jumping, and racing. These rules for registration are simply "rules of sport"- rules that are most efficiently made by the governing body of the organization, it having the incentive to maximize value for its participant members and spectators. Yet, like any rules of sport that by definition must exclude certain equipment in favor of other equipmentwith the idea of horses being akin to equipment explored later in this Article-breed registration standards have become the object of serious antitrust scrutiny. In 2013, the American Quarter Horse Association's rule prohibiting the registration of Quarter Horses produced by cloning was found to violate both Sections 1 and 2 of the Sherman Act. The American Quarter Horse Association did not assert its registration standard as a rule of sport, which would have entitled it to the analytical deference afforded such rules in antitrust cases. Nevertheless, rules that regulate the registration and use of horses in equestrian events are not substantially different from those rules that regulate the use of equipment in other activities and sports-standards that have typically been upheld by courts.

- Mr. Hinkle, J.D. 1972, Yale; B.A. 1969, Washington and Lee University; is a partner at Stoll Keenon Ogden, where he is a member of the firm's board of directors and chairs the firm's litigation department and business litigation practice. Ms. Gall, J.D. 2006, University of Kentucky; MSc 2013, London School of Economics \& Political Science; B.Mus. 2002, Vanderbilt University; is an associate at Stoll Keenon Ogden and a member of the firm's business litigation practice. The authors would like to thank their colleagues, William J. Hunter, Jr., Thomas E. Rutledge, and Brad S. Keeton for their assistance and comments. 
This Article addresses the implications of accepting breed registration standards as "rules of sport," including how in McHugh v. Australian Jockey $C l u b$ the comparison of registration rules to rules of sport influenced the court's decision to reject the applicant's claims that the Australian Jockey Club's rules prohibiting the registration of Thoroughbreds bred by artificial insemination violated Australia's antitrust laws. We begin Part I with an overview of claims under the Sherman Act and how under its structure Abrabam \& Veneklasen Joint Venture v. American Quarter Horse Association was brought and decided. In Part II, we explore why rules on the registration of horses are rules of sport, including the McHugh court's analysis on the matter. In Part III, we discuss the implications for the antitrust analysis when breed registration rules are accepted as rules of sport. Finally, in Part IV, we look briefly at how antitrust claims concerning rules of sport can have perverse effects to devalue the sport.

\section{CLONING THE AMERICAN QUARTER HORSE}

In 2012, Plaintiffs Jason Abraham, Abraham Equine, Inc., and Abraham \& Veneklasen Joint Venture filed suit against the American Quarter Horse Association (AQHA), alleging that Rule 227(a) of the association's Rules and Regulation violated federal antitrust laws by prohibiting the registration of Quarter Horses produced by cloning. ${ }^{1}$ Jason Abraham was a rancher from Canadian, Texas who had approximately 2,500 recipient mares available for cloning. ${ }^{2}$ Abraham also had a contract with Viagen, Inc., which held patents for the use of somatic cell nuclear transfer ("SCNT"), i.e., cloning. ${ }^{3}$ Meanwhile, Dr. Gregg Veneklasen was a veterinarian from Canyon, Texas, specializing in equine reproduction, and

${ }^{1}$ Complaint at 13, Abraham \& Veneklasen Joint Venture v. Am. Quarter Horse Association (AQHA), No. 12 Civ. 00103 (N.D. Tex. Apr. 23, 2012).

${ }^{2}$ Sonny Williams, Gregg Veneklasen's Cloning Quest, QUARTER HORSE NEWS (Feb. 15, 2011), http:/www.quarterhorsenews.com/index.php/news/current-issue-of-qhn/features/10200-greggveneklasens-genetic-quest.html.

${ }^{3}$ Brief of Defendant-Appellant at 5, Abraham \& Veneklasen Joint Venture v. Am. Quarter Horse Association (AQHA), No. 13-11043 (5th Cir. Dec. 26, 2013). 
in particular, cloning. ${ }^{4}$ Through their joint venture, Abraham and Veneklasen owned several Quarter Horses produced by cloning. ${ }^{5}$

The AQHA is a not-for-profit, breed registry dedicated to the Quarter Horse. As noted in its Bylaws, its purpose is:

[T]o collect, record and preserve the pedigrees of American Quarter Horses; to maintain a Stud Book and registry to record the history, breeding, exhibition, and racing of American Quarter Horses; and to stimulate the publicity and improvement of this breed; together with all other matters necessary or convenient to further the interests of the breed. ${ }^{6}$

The science of cloning animals has a relatively short history. It dates back to 1997, when Scottish scientists from the University of Edinburgh revealed that they had produced the first clone of an adult mammal-Dolly, the world's most famous sheep. ${ }^{7}$ In 2003, six years after Dolly, Italian scientists created the world's first cloned horse-Promotea, a Haflinger mare. ${ }^{8}$ Five years later, Promotea became the first clone to reproduce. Advances in cloning continued, and in 2006, Viagen succeeded in creating a clone of Royal Blue Boon, a cutting horse registered with the AQHA. ${ }^{10}$

The process of cloning is simpler to explain than to successfully execute. DNA from the cells of a donor horse is transferred into mature oocytes gathered from the recipient mare. Oocytes are simply eggs from which the genetic material has been removed. Sperm extract is used to

${ }^{4}$ Id. at 22; Williams, supra note 3 .

${ }^{5}$ Brief of Defendant-Appellant, supra note 4, at 44.

6 American Quarter Horse Association Bylaws, Art. 1, Sec. 2, AQHA, http://aqha.com/Resources/2014-Handbook/Corporation-Bylaws/Article-I.aspx_(last visited Oct.15, 2014).

7 Nicolas Wade, The Clone Named Dolly, N.Y. Times (Oct. 14, 2013), http://www.nytimes.com/2013/10/14/booming/the-clone-named-dolly.html?_r=0.

8 John Nielsen, World's First Cloned Horse Born, NPR (Aug. 6, 2003, 12:00 AM), http://www.npr.org/templates/story/story.php?storyId=1387175; Stacy Pigott, Horse cloning technology dates to 2003, AMARILLO GLOBE-NEWS (July 29, 2013, 11:25 PM), http://amarillo.com/news/localnews/2013-07-29/equine-cloning-technology-dates-2003.

${ }^{9}$ Nielsen, supra note 9; Pigott, supra note 9.

${ }^{10}$ Sherri L. Barclay, Mirror, Mirror: A Look at ViaGen/Encore Cloning Process, HORSE GAZETTE (June 2006), http://www.horsegazette.com/Monthly_Features/06-June/Mirror.html. 
stimulate the oocyte to replicate fertilization and form an embryo. The embryo is then transferred into the uterus of the recipient mare, and if everything goes to plan, the embryo will develop into a fetus, which will eventually be born. ${ }^{11}$ The cloned animals are genetically identical. Success rates, however, remain fairly low. ${ }^{12}$ Only $25 \%$ of embryos result in a live birth. ${ }^{13}$ Additionally, about half of cloned foals will present with abnormalities upon birth. ${ }^{14}$ Nonetheless, cloning-when successful-solves certain dilemmas faced by breeders. For instance, cloning allows for the reproduction of horses that are gelded early in life to enable more effective training and performance. ${ }^{15}$ It also allows owners to "bank" genetic material, providing the owner the option of later reproducing a horse that was prematurely lost due to illness or injury before it could be bred. Thus, it was not surprising that Abraham and Veneklasen invested so heavily in perfecting this technology, and in turn, challenged registration standards which they perceived as inhibiting their entry to the breeding and racing markets.

Most breed registry associations explicitly prohibit the registration of horses produced by cloning. In addition to the AQHA, registries for the Appaloosa, Arabian, Freisian, Haflinger, Lippizan, Morgan, Paint Horse, and Thoroughbred have rules that directly or indirectly exclude cloned horses from registration. ${ }^{16}$ The AQHA responded to the issue of registering clones in 2004 when it adopted Rule 227(a), which stipulated:

${ }^{11}$ Kaye Meynell, Cloning: Reproducing the Original?, PASO FINO HORSE WORLD (Mar./Apr. 2013), http://vpub.boyd-printing.com/display_article.php?id=1326899.

${ }^{12} \mathrm{Id}$.

${ }^{13} \mathrm{Id}$.

${ }^{14} \mathrm{Id}$.

${ }^{15} \mathrm{Id}$.

${ }^{16}$ See Appaloosa Horse Club (ApHC) Official Handbook, Rule 205H, APPALOOSA HORSE CLUB, available at http://www.appaloosa.com/pdfs/rulebook14.pdf ("No horse that is produced from cloning shall be registered with the ApHC ${ }^{n}$ ); World Arabian Horse Organization (WAHO) Conference, Doha, Qatar, Nov. 1-8, 2011, WORLD ARABIAN HORSE ORGANIZATION, Rule 19, available at http://www.waho.org/waho-2011-conference.html ("[I]t remains a mandatory WAHO rule that any Arabian of any age produced by cloning and that the foals of any Arabian which was produced by cloning must not be registered under any circumstances."); Fresian Horse Society (FHS) Breed Book Regulations, Rule 2.13, FRESIAN HORSE SOCIETY BREED, available at http://www.friesianhorsesociety.citymaker.com/f/2012_BBR_7-10-2012.pdf ("Cloning will not be allowed"); American Haflinger Society Rules, Rule 22, AMERICAN HAFLINGER REGISTRY, available at http://www.haflingerhorse.com/documents/AHR_Rules_regulations.pdf ("No Haflinger born as the result of cloning will be registered with the American Haflinger Registry"); Registration Guide, Rule 4, UNITED STATES LIPIZZAN FEDERATION, available at http://www.uslipizzan.org/files/uslf- 
Horses produced by any cloning process are not eligible for registration. Cloning is defined as any method by which the genetic material of an unfertilized egg or an embryo is removed and replaced by genetic material taken from another organism, added to/with genetic material from another organism or otherwise modified by any means in order to produce a live foal. ${ }^{17}$

The issue was raised again at the 2008 AQHA Convention when the Stud Book and Registration Committee (SBRC) considered a proposed change to Rule 227(a) that would allow a live foal produced through SCNT to be registered if its DNA matched that of a registered American Quarter Horse. ${ }^{18}$ The SBRC, which is comprised of approximately 25-35 members, recommended postponing any decision on the proposed rule change until a study of the issues could be undertaken. ${ }^{19}$

The proposed change was again on the agenda at the 2009 AQHA Annual Convention, where the AQHA sponsored a cloning forum. ${ }^{20}$ Decision on the proposed change, however, was again delayed pending further study by a cloning task force. ${ }^{21}$ Information gathered by the task force, as well as the results from a member survey wherein an overwhelming

registration-guide.pdf ("A Recorded Clone is not a registered Lipizzan"); Frequently Asked Questions, FAQ\#33, AMERICAN MORGAN HORSE ASSOCIATION, available at

http://www.morganhorse.com/about_morgan/faqs/\#33 ("AMHA will not allow registration of any horses produced by cloning"); 2014 Official American Paint Horse Association (APHA) Rule Book, RG023C \& RG-123, AMERICAN PAINT HORSE ASSOCIATION, available at

http://apha.com/docs/default-source/rule-books/2013rulebookindesign-12914.pdf?sfvrsn=0 ("Horses produced by any cloning process are not eligible for registration"); The American Stud Book Principal Rules and Requirements, Rule 1D, THE JOCKEY CLUB, available at

https://www.registry.jockeyclub.com/registry.cfm?page=tjcRuleBook ("[A]ny foal resulting from ... cloning or any other form of genetic manipulation not herein specified, shall not be eligible for registration").

${ }^{17}$ American Quarter Horse Association Registration Rules \& Regulations, Sec. II, 2, http://services2.aqha.com/iphonedev/www/sections/sectionII/rules/227.html (last visited Oct. 15, 2014) (noting it appears that in the wake of the court's ruling, the AQHA may have eliminated Rule 227(a). Indeed, the language previously found at Rule 227, Horses Not Eligible for Registration, has now been supplanted by Reg. 106, Horses Not Eligible for Registration, available at http://www.aqha.com/Resources/2014-Handbook.aspx\#/Resources/2014Handbook/Registration/REG106-Horses-Not-Eligible-For-Registration.aspx).

${ }^{18}$ AQHA Cloning Timeline, AQHA, available at http://www.aqha.com/AQHA-CloningLawsuit-Resources/AQHA-Cloning-Timeline. aspx (last visited Oct. 15, 2014).

${ }^{19} \mathrm{Id}$.

${ }^{20} \mathrm{Id}$.

${ }^{21} I d$. 
majority of respondents indicated they were against cloning, were presented to the SBRC at the 2010 AQHA Annual Convention. ${ }^{22}$ Based on this information, the SBRC recommended the proposed change be denied, and the membership attending the Convention agreed. ${ }^{23}$ Several more proposed changes to Rule 227(a) were submitted at the 2011, 2012, and 2013 Annual Conventions. ${ }^{24}$ All were considered by the SBRC, which recommended that each be denied. ${ }^{25}$ Soon after the 2012 AQHA Annual Convention, Abraham and Veneklasen brought suit against the AQHA in the U.S. District Court for the Northern District of Texas. They alleged that Rule 227(a) is anticompetitive in violation of both Sections 1 and 2 of the Sherman Act and asked that the court enjoin the AQHA from enforcing its prohibition on the registration of cloned horses and their offspring. ${ }^{26}$ Following a jury trial, Abraham and Veneklasen succeeded on both claims.

Section 1 of the Sherman Act prohibits contracts, combinations, or conspiracies in restraint of trade. ${ }^{27}$ Courts have consistently held, however, that in practice the Sherman Act only prohibits unreasonable restraints. ${ }^{28}$ Indeed, in its Memorandum Order on the AQHA's Motion for Summary Judgment, the court explained that Section 1 "calls for a two-step analysis: (1) whether an arrangement is a contract, combination, or conspiracy; and (2) whether the contract, combination, or conspiracy unreasonably restrains interstate or foreign trade. ${ }^{29}$

With respect to the first step of the analysis, the AQHA asserted in its Motion for Summary Judgment that it is entitled to single entity protection because its decision to continue to enforce Rule 227(a) is the decision of a single entity and not concerted action by and between members of the

\footnotetext{
${ }^{22} I d$.

23 Id.

${ }^{24}$ AQHA, supra note 19.

${ }^{25}$ Id.

${ }^{26}$ Id. (stating that though the plaintiffs also made claims under the Texas Free Enterprise and Antitrust Act, this Article focuses on only those brought under Federal law.)

2715 U.S.C. $\$ 1$ (2004).

${ }^{28}$ See, e.g., Nw. Wholesale Stationers vs. Pac. Stationary \& Printing Co., 472 U.S. 284, 289

29 Memorandum Order on AQHA's Motion for Summary Judgment, at 4-5, Abraham \& Veneklasen Joint Venture v. Am. Quarter Horse Ass'n, No. 12 Civ. 00103, 2013 U.S. Dist. LEXIS 73754 (N.D. Tex. May 24, 2013).
} (1985). 
SBRC and the AQHA. ${ }^{30}$ Nonetheless, concerted activity alone is not sufficient to violate Section 1 . Concerted activity must result in an unreasonable restraint on trade. While certain concerted activities are treated as per se violations of Section 1, most actions are reviewed for reasonableness under the Rule of Reason; particularly where the action is a rule of a non-profit association that regulates sporting tournaments, races, and other contents. ${ }^{31}$ The AQHA's enforcement of Rule 227(a) was submitted to the jury with instructions to consider the issue under the Rule of Reason, pursuant to which the fact-finder must decide whether the questioned practice has a legitimate justification. ${ }^{32}$ Typically, to establish that the practice has a legitimate justification, the defendant must put forward evidence of its pro-competitive effects. ${ }^{33}$ In its Appeal Brief, the AQHA submitted arguments that Rule 227(a) was justified by the AQHA's need to accurately record pedigrees and prevent the spread of genetic diseases. ${ }^{34}$ The AQHA did not put forward any arguments that the enforcement of Rule 227(a) is necessary to preserve the integrity of the activity and sport of Quarter Horse breeding and racing. ${ }^{35}$

${ }^{30}$ Brief for Summary Judgment of Defendant at 7, Abraham \& Veneklasen Joint Venture v. Am. Quarter Horse Ass'n, No. 12 Civ. 00103 (N.D. Tex. Mar. 25, 2013). As further explained in Part III, infra, the single entity defense exempts an entity from Section 1 antitrust liability because an entity cannot conspire with itself. See Copper Weld Corp. v. Independence Tube Corp., 467 U.S. 752 (1984).

${ }^{31}$ See, e.g., Gunter Harz Sports, Inc. v. U.S. Tennis Ass'n., 511 F. Supp. 1103, 1114-15 (D. Neb. 1981) (citing Hatley v. Am. Quarter Horse Ass'n, 552 F.2d 646 (5th Cir. 1977)); Deesen v. Prof' Golfers' Ass'n of Am., 358 F.2d 165 (9th Cir. 1966), cert. denied, 385 U.S. 846 (1966), and rehearing denied, 87 S. Ct. 738 (1967); Blalock v. Ladies Profl Golf Ass'n, 359 F. Supp. 1260 (N.D. Ga. 1973); Heldman v. U.S. Lawn Tennis Ass'n, 354 F. Supp. 1241 (S.D.N.Y. 1973); STP Corp. v. U.S. Auto Club, Inc., 286 F. Supp. 146 (S.D. Ind. 1968)).

${ }^{32}$ Jury Charge at 10, Abraham \& Veneklasen Joint Venture v. Am. Quarter Horse Ass'n, No. 1311043 (5th Cir. Aug. 22, 2013).

33 Nat'l Collegiate Athletic Ass'n v. Bd. of Regents, 468 U.S. 85, 117-20 (1984); Worldwide Basketball and Sport Tours, Inc. v. NCAA, 388 F.3d 955, 959 (6th Cir. 2004). An alternative approach is discussed in Part III, infra.

${ }^{34}$ Brief of Defendant-Appellant, supra note 4, at 44.

${ }^{35}$ Justifications related to the public interest or the integrity of the industry are generally insufficient without an economically pro-competitive reason. See, e.g., Nat'l Soc'y of Prof'l Eng'rs v. U.S., 435 U.S. 679, 695 (1978). Indeed, the antitrust analysis focuses "exclusively on the challenged restraint's impact on competitive conditions... [it is] "not designed to protect the convenience or financial benefits of the conspirators or even other entities involved in the industry." Gen. Cinema Corp. v. Buena Vista Distrib. Co. Inc., 532 F. Supp. 1244, 1267 (C.D. Cal. 1982). Instead, the purpose of the antitrust analysis is "to form a judgment about the competitive significance of the restraint; it is not to decide whether a policy favoring competition is in the public interest, or in the interest of the members of an industry." Nat'l Soc'y of Prof'l Eng'rs, 435 U.S. at 692. Nonetheless - and as described further in Section 3, infra - when a standard is put forward as "rule of sport," non-economic justifications are often considered by the courts. 
Meanwhile, Section 2 of the Sherman Act prohibits monopolization of "any part of the trade or commerce." ${ }^{\text {" }}$ Any analysis of a Section 2 claim commences with a definition of the relevant product and geographic markets, which are typically the parts of the "trade or commerce" that have purportedly been monopolized. ${ }^{37}$ The relevant markets provide the framework against which economic power can be measured..$^{38}$ This was a threshold issue at trial because the more narrow the market definition, the greater the market effect. Abraham and Veneklasen defined the relevant product market as that for the "elite" Quarter Horse. According to the AQHA's appeal brief, the plaintiffs described the "elite" Quarter Horse market as being comprised of approximately five-percent of registered Quarter Horses, horses which are "high quality," "best of the best," and "top-drawer." 39 Abraham and Veneklasen further described "elite" Quarter Horses as coming from desirable bloodlines, having succeeded in competitions, and fetching high prices. ${ }^{40}$

Naturally, the AQHA took significant issue with this definition. The AQHA argued that it provided for no permanent boundaries, as a Quarter Horse with desirable bloodlines may fetch a high price early in life but later prove a competitive failure and vice versa. ${ }^{41}$ In other words, "eliteness" is an impermanent status. A recent example-albeit not a Quarter Horse-is that of California Chrome, which in 2014 was considered a serious contender for the Triple Crown after winning the Kentucky Derby and Preakness. California Chrome would not have been considered an "elite"

${ }^{36} 15$ U.S.C. $\$ 2$ (2004).

${ }^{37}$ Defining the relevant markets is also a necessary part of most analyses under Section 1 of the Sherman Act. As explained by the authors of Antitrust Law Developments (Seventh), "the definition of the relevant market is so central that it may determine the final outcome of the case. ... Application of the rule of reason [under Section 1 of the Sherman Act] ... typically requires a detailed examination of the restraint's actual competitive impact in a properly defined relevant market. Under Section 2 of the Sherman Act, defining the relevant market is essential to proving monopolization or attempted monopolization." JONATHAN I. GLEKLEN ET AL.,1 ANTITRUST LAW DEVELOPMENTS 569 (7th ed. 2012).

${ }^{38}$ Id. (citing Walker Process Equip. v. Food Mach. \& Chem. Corp., 382 U.S. 172, 177 (1965), accord Spectrum Sports, Inc. v. McQuillan, 506 U.S. 447, 456 (1993) ("In order to determine whether there is a dangerous probability of monopolization, courts have found it necessary to consider the relevant market and the defendant's ability to lessen or destroy competition in that market.").

${ }^{39}$ Brief of Defendant-Appellant, supra note 4, at 30.

${ }^{40}$ Brief of the Plaintiffs-Appellees at 8-11, Abraham \& Veneklasen Joint Venture v. Am. Quarter Horse Ass'n, No. 13-11043 (5th Cir. Feb. 27, 2014).

${ }^{41}$ Brief of the Defendant-Appellant, supra note 4, at 30-31. 
Thoroughbred at the time his owners bred him for a mere $\$ 10,000 .^{42}$ Today, California Chrome is rumored to be worth over $\$ 12$ million. ${ }^{43}$ Regardless, it is apparent that when the definition of the relevant product market is narrowed to that of the "elite" Quarter Horse, the likelihood of the AQHA monopolizing that market increases given that AQHA registration is essential to participation in the most lucrative Quarter Horse events.

Monopoly power by itself, however, is not unlawful. Rather, monopoly power is only unlawful when it is acquired or maintained through anticompetitive conduct-conduct without a legitimate business purpose. ${ }^{44}$ Thus, the importance of establishing a legitimate business purpose again becomes crucial. Yet, as with its Section 1 defense, the AQHA did not assert that Rule 227(a) is necessary as a "rule of sport" to maintain the integrity of Quarter Horse breeding and racing. Instead, it chose to concentrate on justifications related to accurate recording and the prevention of unknown genetic disease, as well as respecting the sentiment of its membership.

As previously noted, the AQHA's enforcement of Rule 227(a) was found to violate both Sections 1 and 2 of the Sherman Act. Though the jury did not award Plaintiffs any damages, the court enjoined the AQHA from enforcing Rule 227(a) and ordered it to register clones of Quarter Horses and the offspring of cloned Quarter Horses. ${ }^{45}$ The injunction has been stayed pending outcome of the AQHA's appeal to the Fifth Circuit. ${ }^{46}$

${ }^{42}$ Greg Price, Preakness 2014: California Chrome Cost $\$ 10,000$, But What's The Real Cost Of A Racehorse?, INT'L BUS. TIMES (May 16, 2014, 10:26 AM), http://www.ibtimes.com/preakness-2014california-chrome-cost-10000-whats-real-cost-racehorse-1585046.

${ }^{43}$ Id.

44 See 21 Cong. Rec. 3151-52 (1890) (Section 2 of the Sherman Act) (explaining that the Sherman Act was not directed against one "who happens by his skill and energy to command a legitimate monopoly of a business"). See also Morris Commc'ns. Corp. v. PGA Tour, Inc., 364 F.3d 1288,1295 (11th Cir.) ("Unlawful monopoly power requires anticompetitive conduct, which is conduct without a legitimate business purpose be that makes sense only because it eliminates competition.") (citing Conwood Co., L.P. v. U.S. Tobacco Co., 290 F.3d 768 (6th Cir. 2002); Gen. Indus. Corp. v. Hartz Mountain Corp., 810 F.2d 795, 804 (8th Cir. 1987); LePage's Inc. v. 3M, 324 F.3d 141, 153-54 (3d Cir. 2003).

${ }^{45}$ Final Judgment at 1, Abraham \& Veneklasen Joint Venture v. Am. Quarter Horse Ass'n, No. 2:12-cv-00103-J (N.D. Tex. Aug. 22, 2013).

${ }^{46}$ On September 4, 2014, the Fifth Circuit Court of Appeals heard oral arguments in the AQHA's appeal of the District Court's decision. It is not known when the Fifth Circuit might issue its decision. 


\section{REGISTRATION STANDARDS AS RULES OF SPORT}

\section{A. McHugh v. Australian Jockey Club}

A result very different from that of $A Q H A$ was reached in $M c H u g h v$. Australian Jockey Club. ${ }^{47}$ There, Bruce McHugh, a Thoroughbred breeder, former chairman of the Sydney Turf Club, and bookmaker sued the Australian Jockey Club, the Victoria Racing Club, and the Australian Turf Club seeking relief from their rules prohibiting registration and racing of Thoroughbreds produced by artificial insemination. The restrictions at issue included those rules from the Australian Stud Book, which provide that in order to be eligible for registration, a foal must be the product of natural service, and specifically, could not be the product of artificial breeding. ${ }^{48}$ Also at issue were certain Australian Rules of Racing, which require that a horse be registered with the Australian Stud Book before it can be entered in any race. ${ }^{49}$

$\mathrm{McHugh}$ argued that because a foal cannot be registered with the Australian Stud Book if it is the product of artificial insemination, it also cannot be registered with the Registrar of Racehorses. ${ }^{50}$ As a result, a foal that is the product of artificial insemination may not race in any race sanctioned by the Australian Racing Board. McHugh claimed that together these rules (i) violate $\$ 45(2)(b)(i i)$ of the Australian Competition and Consumer Act 2010 (the "ACCA"), which prohibits contracts with the purpose or likely effect of substantially lessening competition, and (ii)

${ }^{47}$ McHugb v. Australian Jockey Club Limited (No. 13), (2012) FCR 1441 (Austl.), available at http://www.austlii.edu.au/au/cases/cth/FCA/2012/1441.html.

${ }^{48}$ Rules Of The Australian Stud Book, DIV. OF RACING INFO. SERV. AUSTL. PTY. LTD. (RISA), 1, 18-19, http://www.studbook.org.au/DisplayPDF.aspx?ty=RULES_(last updated Sept. 17, 2014).

${ }^{49}$ Australian Rules of Racing, AUSTRALIAN RACING BOARD, 1, 17 (July 1, 2010), http://www.australianracingboard.com.au/uploadimg/Rules\%20010710.pdf.

${ }^{50}$ See McHugh, supra note 48, at 1466. 
constitute an impermissible restraint of trade under the common law. ${ }^{51}$ The court rejected Mr. McHugh's arguments in its lengthy decision issued in December 2012.52

Though Section 45 of the ACCA is not a perfect analogy to Section 1 of the Sherman Act, it is substantially similar. ${ }^{53}$ Indeed, U.S. antitrust law begat Australia's Trade Practices Act 1974, the former name of the ACCA. ${ }^{54}$ Recognizing the influence of U.S. law, particularly through its discussion of Brookins v. International Motor Contest Ass' ${ }^{55}$, the court reasoned that $\mathrm{McHugh}$ had failed to establish that the defendants had given effect to a provision of a contract, arrangement, or understanding where the provision had the effect, or was likely to have the effect of substantially lessening competition. ${ }^{56}$ The court's reasons for its decision included:

- The insufficiency of the evidence directed to establishing substantial lessening of competition;

- The insufficiency of evidence as to the pleaded contracts, arrangements or understandings;

- The status of the Rules at issues as "Rules of Sport;" and,

- The sufficiency of evidence concerning the international consequences of finding the Rules anticompetitive - that is, if the Rules were overturned

${ }^{51}$ McHugh, supra note 48, at summary.

${ }^{52}$ On October 17, 2014, the Australian High Court denied McHugh's request for special leave to appeal. The High Court's decision ended McHugh's efforts to overturn the rules which prohibit registration of Thoroughbreds bred by artificial insemination. See DRF Breeding Staff, Bid for artificial insemination ends in Australia, DAILY RACING FORM (Oct. 17, 2014), http://www.drf.com/news/bidartificial-insemination-ends-australia.

53 See id.; Legislation, AUSTL. CONSUMER LAW, http://www.consumerlaw.gov.au/content/content.aspx?doc=the_ac//legislation.htm (last visited Oct. 15, 2014).

${ }^{54}$ See Paul G. Scott, The Impact of US Antitrust on Aspects of New Zealand Competition Law (unpublished paper) available http://www.law.nyu.edu/sites/default/files/upload_documents/PaulScott.pdf); Legislation, supra note 53.

${ }^{55}$ Brookins v. Int'l Motor Contest Ass'n, 219 F.3d 849 (8th Cir. 2000).

${ }^{56}$ See McHugh, supra note 48, at 9 1524-25. (With respect to the common law restraint of trade claim, the court reasoned that Mr. McHugh had failed to establish that the restraint was unreasonable at the time it was imposed in 1947, particularly given that $\mathrm{Mr}$. McHugh accepted the reasonableness of the alleged restraints at the time they were imposed many decades ago to prevent the attribution of incorrect paternity to a thoroughbred horse.) 
in Australia, then the status of Australian Thoroughbred races would be downgraded. ${ }^{57}$

Though it is not apparent whether the court's conclusion was dependent on a balancing of all its reasons or whether any one of its reasons alone would serve as the basis for dismissing the applicant's claims, this Article is primarily concerned with the court's treatment of the contested provisions as "rules of sport." The provisions' status as "rules of sport" critically bore on how the court analyzed whether the impugned provisions had or were likely to have "the effect of substantially lessening competition once their offsetting, pro-competitive benefits had been accounted for. ${ }^{\text {} 58}$ Arguably, the rules' status was determinative to the court's ultimate question of whether their enforcement violated Australia's antitrust laws.

The primary concern for the court in conferring rule of sport status was whether the rules being challenged were significant to the sport of Thoroughbred racing. ${ }^{59}$ Keeping this in mind, the court referred to-and to a certain extent was influenced by-the U.S. Court of Appeals' decision in Brookins. ${ }^{60}$ Given the McHugb court's reference to and reliance on Brookins, this decision deserves exploration.

In Brookins, the automobile defendant racing association, IMCA, had banned from its races the use of certain transmissions manufactured by the plaintiffs. ${ }^{61}$ The plaintiffs argued that exclusion of their transmissions from IMCA-sanctioned races had an adverse effect on competition by depriving drivers of less expensive, safer, better-performing products. The court rejected this argument, calling the plaintiffs' analysis flawed. ${ }^{62}$ It found that the IMCA restriction, rather than having an adverse effect on competition, merely "help[s] define a game or sport in which the end product is a form

\footnotetext{
${ }^{57}$ McHugh, supra note 48, at summary.

s8 Id. at $\nabla 1445$.

${ }^{59} I d$ at 91446.

${ }^{60}$ Brookins, 219 F.3d 849.

${ }^{61}$ Id. at $851-52$.

${ }^{62}$ Id. at 853 .
} 
of competition among drivers. ${ }^{\text {"33 }} \mathrm{McHugh}$ found the following from Brookins particularly insightful:

Without question, the way IMCA defines the rules for modified car racing will exclude some types of equipment. But the exclusion is an incidental and inevitable by-product of defining the game. A rule making body's impact on equipment manufacturers will vary depending on the popularity of the game, and the extent to which its rules are followed by the game's players - in other words, the extent to which they are seen as rules of the game itself, rather than rules of that body's league of game-players. ${ }^{64}$

Though McHugb conceded that it would need to consider Brookins carefully given the distinct statutory context of U.S. antitrust law, there is little doubt that the foregoing language shaped the court's question as to "whether the impugned provisions deal only with an irrelevant, because [sic] not performance-affecting, mode of conception" as Mr. McHugh contended, or "whether the method of conception, as between natural cover and artificial insemination, is an attribute of the sport of Thoroughbred racing," as the defendants contended. ${ }^{65}$

In determining the answer, McHugh placed considerable weight on evidence that suggested a core feature of Thoroughbred racing is the breeding of its horses by natural cover, without which a "large part of the fabric of the industry" would be lost. ${ }^{66}$ Though the court rejected evidence suggesting the difficulty of conception by natural cover (as opposed to the difficultly of breeding a champion) contributes to an attribute of the sport, ${ }^{67}$ it recognized that breeding by natural cover remained a part of the "mystique and inherent skill of Thoroughbred racing. ${ }^{n 68}$ In response to

${ }^{63} I d$. at 853-54 (explaining that in these circumstances [where the exclusion is incidental result of defining the rules of the game], IMCA rules are not the kind of 'naked restraint' on competition that justify foregoing the market analysis normally required in Section 1 rule-of-reason cases").

${ }^{64}$ McHugh, supra note 48, at 1449 (quoting Brookins, 219 F.3d at 853) (emphasis added).

${ }^{65}$ Id. at 1452 (emphasis added).

${ }^{66}$ Id. at 91457.

${ }^{67} \mathrm{Id}$. at $1 \mathrm{I} 1458$.

${ }^{68} I d$. at 91457 . 
McHugh's contention that the impugned provisions merely set forth who might participate in the game, the court "rejected any distinction between rules that define the game and rules that define who may play the game. ${ }^{769}$ It reasoned that many sports are defined by who plays in the game, and that regardless; the horses themselves do not play the game of Thoroughbred racing. ${ }^{70}$ The court concluded that horses are more like equipment in the game of Thoroughbred racing, rather than players. ${ }^{71}$ Finally, and perhaps most significantly, the court recognized that that it should provide a not insignificant amount of deference to the governing organizations making the rules as it is those organizations which have to judge "what is in the best interests of the sport in terms of its appeal" by taking into account the opinions of its "breeders, owners, punters, and other spectators." ${ }^{72}$ Indeed, this propriety of affording such deference is explored further in Section 4.

Considering the evidence, McHugh found that the impugned provisions "contribute to the nature and quality of the sport and are an attribute of it." ${ }^{13}$ Drawing further upon the comparison of horses as sporting equipment, the court found that:

[T]horoughbred racing, is defined by reference to breeding so the mode of conception or "manufacture" is closer to the heart of the sport than, say, a prescription in tennis as to the mode of manufacture of a tennis racquet so as to require that racquets be handmade. In the case of thoroughbred racing the existing construct, involving the existing and unchallenged rules about breeding lines, involves humans racing thoroughbred horses bred from those breeding lines so as to exclude thoroughbred horses bred from those lines by artificial insemination.

Thus the impugned provisions have procompetitive effects in that they contribute to the interest of those who participate in

\footnotetext{
${ }^{69} \mathrm{Id}$. at 91460.

${ }^{70}$ McHugh, supra note 48 , at 1460 .

${ }^{71}$ Id. at 91461.

${ }^{72}$ Id. at 1454.

${ }^{73}$ Id. at If 1463.
} 
the sport whether as breeders, owners, punters or other
spectators.

Though the court was "not able to quantify either the extent of the contribution of the impugned provisions to the total value of the sport or the extent to which, if those provisions were held to be contrary to $\$ 45$, the demand [for the sport] would diminish," it was still "satisfied that there would be reduced competition in the absence of the impugned provisions." ${ }^{75}$ Accordingly, it followed for the court that horses bred by artificial insemination could not be competitors in a market defined by breeding by natural cover. ${ }^{76}$

McHugh's findings benefit from clarification. As previously noted, the court's analysis of the "impugned provisions" as "rules of sport" was intended to determine whether the restriction on registration of horses bred by artificial insemination had or was likely to have the effect of substantially lessening competition once the restriction's off-setting procompetitive benefits were accounted for. ${ }^{77}$ In its analysis, the court found that the restriction, which was close to the "heart" of Thoroughbred racing, produced certain procompetitive effects by contributing to the interests of the sport's participants. ${ }^{78}$

It is worth noting that in determining whether the restriction was likely to have the effect of substantially lessening competition, the court did not explicitly weigh and balance its procompetitive effects against any anticompetitive effects. Presumably, that is because earlier in its opinion the court found no evidence to support the applicant's contention that the restriction had any anti-competitive effects. ${ }^{79}$ It is not clear why given the

${ }^{74} I d$. at $\$ 11463-64$ (emphasis added).

${ }^{75}$ Id. at 91464.

${ }^{76}$ McHugh, supra note 48 , at 11465.

${ }^{77}$ Id. at 1445.

${ }^{78}$ Id. at $991463-64$.

79 "Of themselves the ASB Provisions do not have an effect on competition in the relevant market since they do no more than state which horses may be entered in that register. By themselves, the ASB Provisions do not relevantly restrict or prohibit a thoroughbred horse from racing in a thoroughbred race." Id. at $\$ 1429$. "[T] he applicant did not establish any substantial lessening of competition as he did not establish there were likely to be meaningful changes in the decisions made by mare and/or stallion owners as a result of the removal of the impugned provisions. The applicant did not establish that if artificial insemination were available for thoroughbred breeding then breeding costs would be lower to a degree which was significant in light of the overall costs of the breeding decision to be made; that mare 
lack of any anticompetitive effect the court felt it necessary to establish the provisions' procompetitive benefits. Perhaps the court merely wished to engage in a fulsome analysis. However, the lack of anticompetitive effect flowing from the prohibition on artificial insemination may be significant to the court's ultimate finding that without the restriction there might be reduced competition in the sport. ${ }^{80}$ In other words, because the restriction goes to the heart of sport-because it helps define the sport-its absence might deter participants from engaging in the sport if without the restriction Thoroughbred racing is less exciting, less engaging, or simply not the same sport its participants and spectators have come to know.

We do not discuss $\mathrm{McHugh}$ for the purpose of redefining the antitrust analysis under either Sections 1 or 2 of the Sherman Act. In fact, no redefinition is needed given that the analytical construct of $M c H u g h$ is largely consistent with other "rules of sport" cases where the court applies the Rule of Reason to determine whether the rule at issue runs afoul of antitrust laws. Rather, McHugb is primarily offered to understand that breed registry standards are no different than any other rules of sports which specify what equipment may be utilized-rules that have typically been upheld by U.S. courts under analyses similar to $\mathrm{McHugh.}{ }^{81}$ Brookins is one such case. Because these "rules of sport" cases have been examined in depth by other authors, only a few more are reviewed below for the purpose of helping the reader understand guiding precedents.

owners would so expand the geographic range in which they sought stallion services; or that owners of high quality stallions would so expand their output." Id. at \$ 1433. "It is not enough to find that, for example, the costs of transporting a broodmare to stud matters to some of those breeders who gave evidence and from that finding to conclude that giving effect to the impugned provisions would or would be likely to substantially lessen competition." Id. at $\ 1437$. "It follows from my findings that the applicant has failed to establish the claimed increase in competition in the breeding market from the removal of the restrictions in that market that the applicant has not established there would be the flow on effects in the acquisition market, leading to an increase in competition in that market, for which he contended. Further, I am not satisfied that if Al were permitted in Australia there is likely to be an increase in the number of high-quality yearlings put up for sale or that prices were likely to be lower for high-quality yearlings. I am not satisfied that there would be significant demand for AI-bred thoroughbreds in the thoroughbred acquisition market or that international and domestic purchasers seeking to breed or race in Australia only would be likely to purchase AI-bred thoroughbreds." Id. at I 1443.

${ }^{80} \mathrm{Id}$. at $\$ 1464$.

${ }^{81}$ See John E. Lopatka, Antitrust and Sports Equipment Standards: Winners and Whiners, 54 ANTITRUST BULL. 4 at 3-4 (June 2, 2009), available at http://papers.ssrn.com/sol3/papers.cfm?abstract_id=1413172 (explaining that antitrust claims have rarely succeeded on rules defining equipment standards in sport). 


\section{B. Reviewing Antitrust Precedents on "Rules of Sport"}

In Gunter Harz Sports, Inc. v. United States Tennis Ass'n, ${ }^{82}$ the plaintiff manufacturer of tennis racquets challenged the United States Tennis Association's (USTA) decision to adopt the International Tennis Federation's definition of a tennis racquet, a definition which had the effect of excluding the use of "double-strung" racquets from USTA-sanctioned tennis tournaments. The manufacturer alleged that the USTA conspired with others to restrain competition in the sale of tennis racquets in violation of Section 1 of the Sherman Act. The court, recognizing the need for collective action in organized sports, analyzed the USTA's actions under the Rule of Reason pursuant to the 4-part inquiry articulated in Silver v. New York Stock Exchange. ${ }^{83}$ Under the reasoning of Silver, the Rule of Reason inquiry focuses on aspects that differ slightly from the approach applied by most courts. Rather than weighing the restriction's procompetitive benefits against its anticompetitive effects, a court asks:

(1) whether collective action is intended to accomplish an end consistent with the policy justifying selfregulation;

(2) whether the action is reasonably related to that goal;

(3) whether such action is no more extensive than necessary; and

(4) whether the association provides procedural safeguards which assure that the restraint is not arbitrary and which furnish a basis for judicial review. ${ }^{84}$

Though the court did not explain why it chose to avoid the traditional approach to Rule of Reason analysis, it did note that the inquiry from Silver is applied in "areas where a need for self-regulation is inherent in the

\footnotetext{
${ }^{82}$ Gunter Harz Sports, Inc. v. U.S. Tennis Ass'n, Inc., 511 F.Supp. 1103 (D. Neb. 1981).

${ }^{83}$ Silver v. New York Stock Exch., 373 U.S. 341 (1963).

${ }^{84}$ Gunter Harz, 511 F. Supp. at 1116.
} 
industry," including professional and amateur sports. ${ }^{85}$ Applying this inquiry, the court found that the rule banning double-strung racquets was adopted to address the USTA's goal of preserving the character and integrity of the game of tennis. ${ }^{86}$ The court concluded that this was a legitimate goal, that the rule was reasonably related to achieving that goal, and that the rule was no more extensive than necessary to serve that goal. ${ }^{87}$

Importantly, the court emphasized that in the absence of evidence demonstrating that the sanctioning organization acted in an unlawful, arbitrary, or malicious manner, the court must provide that organization with a certain amount of latitude in determining what is a legitimate goal and the rules appropriate to reach that goal. ${ }^{88}$ Quoting from STP Corp. v. United States Auto Club, the court emphasized that membership organizations, such as the USTA, "have the right to adopt such rules to protect their very existence. ${ }^{n 99}$ The court also addressed the fourth inquiry, rejecting the idea that the actions of the USTA must be a "model of procedural due process." ${ }^{\prime \prime 0}$ Rather, its notice and comment period, which provided every interested party an opportunity to be heard, was sufficient; ${ }^{91}$ the USTA was not required to provide the plaintiff with a personal hearing. ${ }^{92}$ Significantly, the court recognized that while the ban negatively impacted the plaintiff manufacturer's ability to compete in the market for tennis racquets, this effect was merely "incidental to the USTA's primary purpose in promoting tennis competition."

In Weight-Rite Golf Corp. v. United States Golf Ass'n, the plaintiff manufacturer of golf shoes alleged that the United States Golf Association (USGA), a non-profit association of golf courses and golf clubs, ran afoul of Sections 1 and 2 of the Sherman Act by determining that the use of

${ }^{85}$ The traditional approach to the Rule of Reasons as compared to the alternative approach set forth in Gunter Harz is discussed again in Section 3, including to what extent these two approaches might be inconsistent with one another. See Silver, 373 U.S. at 362.

${ }^{86}$ Gunter Harz, 511 F. Supp. at 1119.

${ }^{87} \mathrm{Id}$. at $1118-19$.

${ }^{88} \mathrm{Id}$. at $1117-18$.

${ }^{89}$ STP Corp. v. U.S. Auto Club, Inc., 286 F.Supp. 146, 151 (S.D. Ind. 1968).

${ }^{90}$ Gunter Harz, 511 F. Supp. at 1121.

${ }^{91} \mathrm{Id}$ at 1122.

${ }^{92}$ Id.

${ }^{93}$ Id. at 1124. 
Weight-Rite shoes violated its Rules of Golf. ${ }^{94}$ The USGA's Rules are typically followed in professional and amateur golf tournaments, even by entities such as the PGA Tour, which conduct non-USGA golf competitions. ${ }^{95}$ Because the plaintiff completely failed to demonstrate that the USGA had engaged in a conspiracy with its member clubs-indeed, the plaintiff did not even make this assertion-the court could have rested its decision to dismiss the Section 1 claim on this failure alone. ${ }^{96}$ The court, however, proceeded and considered the plaintiff's claim under the Rule of Reason. To succeed on its claim, Weight-Rite had to present evidence that the USGA's determination that Weight-Rite shoes did not conform to the Rules of Golf injured competition in the U.S. golf shoe market. The only evidence offered by Weight-Rite, however, was its suggestion that the USGA had the power to decrease the marketability of certain types of golf shoes and that as a result of the USGA's interpretation of its Rules of Golf, Weight-Rite shoes had been returned and discontinued by many retailers. ${ }^{97}$ These allegations were insufficient, and the court emphasized that injury to oneself as a competitor is not injury to competition. ${ }^{98}$ With no evidence to controvert the USGA's assertion that the purpose of its rule was nothing other than to "preserve the traditions of the game and to insure that a player's score is the product of his skills, rather than his equipment," the plaintiff's claim failed under the Rule of Reason. ${ }^{99}$ Indeed, given the lack of any anticompetitive effect, there was no need for the court to consider what, if any, procompetitive effects result from the USGA's enforcement of its rules.

Another more recent claim involving the USGA was brought in Windage, LLC v. United States Golf Ass' $n^{100}$ by a manufacturer of wind gauges used in golf. The USGA banned the plaintiff's device from competition because it did not conform to a rule of golf that prohibited any

\footnotetext{
${ }^{94}$ Weight-Rite Golf Corp. v. U.S. Golf Ass'n, 766 F. Supp. 1104, 1106 (M.D. Fla. 1991).

${ }^{95} \mathrm{Id}$. at 1108.

${ }^{96}$ See id. at $1108-09$.

${ }^{97} \mathrm{Id}$. at $1110-11$.

${ }^{98} I d$. at 1110.

${ }^{99}$ Id. at 1111 (quoting the Affidavit of Frank Thomas).

${ }^{100}$ Windage, LLC v. U.S. Golf Ass'n, No. Civ. 07-4897, 2008 U.S. Dist. LEXIS 51065 (D.
} Minn. July 2, 2008). 
artificial device that could be used to affect play. ${ }^{101}$ In turn, the plaintiff filed suit alleging that the USGA conspired with its members and affiliates to boycott the plaintiff's wind gauge, and in doing so, restrained trade and inhibited development and research. ${ }^{102}$ The court dismissed the plaintiff's Section 1 claim based on its failure to sufficiently allege an agreement. ${ }^{103}$ In an attempt to create a plausible inference of an agreement, the plaintiff asserted that that the USGA had applied its rules in an arbitrary and inconsistent manner, allowing the use of laser and GPS devices that measured distance, but banning the plaintiff's device that measured wind. ${ }^{104}$ In dismissing this argument, the court cited to Brookins and emphasized:

So long as [the USGA] made game-defining rules decisions based upon its purpose as a sports organization, an antitrust court need not be concerned with the rationality or fairness of those decisions. Irrational decisions and unfair treatment of suppliers will result in an unpopular game, and players and spectators will take their entertainment dollars elsewhere. ${ }^{105}$

The language here is significant. Recall that the first two factors of the four-factor inquiry outlined in Gunter Harz require the restriction at issue be "intended to accomplish an end consistent with the policy justifying selfregulation" and be "reasonably related to that goal." 106 These factors clearly call for rationality. Indeed, even though the McHugb court does not speak precisely in terms of rationality, it goes to great lengths to determine whether the rule prohibiting artificial insemination is a rule that defines the sport of Thoroughbred racing or merely some rule that was instituted by its participants. Yet, both Windage and Brookins reject rationality and in doing so suggest some significantly lesser standard is appropriate. While it is

\footnotetext{
${ }^{101}$ Id. at $* 3-4$.

${ }^{102}$ Id. at $* 4$.

${ }^{103}$ Id. at $" 9-10$.

${ }^{104} I d$. at ${ }^{* 10-11 .}$

${ }^{105}$ Id. at "11 (citing Brookins v. Int'1 Motor Contest Ass'n, 219 F.3d 849, 854 (8th Cir. 2000)).

${ }^{106}$ Gunter Harz, 511 F. Supp. at 1116.
} 
unclear what precisely constitutes this lesser standard, it may have to do with whether the organization's decision was tainted by coercion. ${ }^{107}$

In Warrior Sports, Inc. v. NCAA, the plaintiff was a manufacturer of lacrosse sticks. ${ }^{108}$ It filed a complaint against the NCAA after the NCAA amended its rule regarding the type of lacrosse sticks that could be used in NCAA competition; the NCAA's amendment had the effect of rendering all of Warrior's current lacrosse stick heads illegal. ${ }^{109}$ Warrior contended that the NCAA conspired with its competitors in making this amendment and in doing so inhibited competition and innovation in the lacrosse stick market and thereby violated Section 1 of the Sherman Act. ${ }^{110}$ The case is worth mentioning for two reasons. First, the court engaged, at least preliminarily, in Rule of Reason analysis, demonstrating that courts will continue to look at antitrust challenges to "rules of sport" under the Rule of Reason. Second, although the court recognized that Warrior's claim must be reviewed under the Rule of Reason, the court did not undertake a full Rule of Reason analysis because Warrior failed to meet its initial burden of demonstrating anticompetitive effect. ${ }^{111}$ Significantly, the Sixth Circuit reasoned that Warrior failed to meet its burden of demonstrating injury to competition, rather than injury only to itself, because the rule at issue "applies to all manufacturers, including Warrior, in exactly the same way," and thus, "Warrior may compete in the market on the same footing as all other participants." 112 This is a notable case because the court found that an equally applicable rule eliminates the possibility of anti-competitive effect.

\section{IMPLICATIONS FOR THE ANTITRUST ANALYSIS WHEN STANDARDS FOR REGISTRATION ARE CONSIDERED “RULES OF SPORT"}

${ }^{107}$ Brookins, 219 F.3d at 854 (The court suggests that evidence of coercion in setting the restriction would be sufficient. "[I]f the rules decisions are corrupted by coercion from competitors of the disadvantaged supplier, we have a different antitrust setting, ... ." but " $[t]$ here is no evidence that the IMCA's rulings were made for reasons other than its overall purpose to define a set of rules for a popular game.").

${ }_{108}$ Warrior Sports, Inc. v. Nat'l Collegiate Athletic Ass'n, 623 F.3d 281 (6th Cir. 2010).

${ }^{109} \mathrm{Id}$.

${ }^{110} I d$. at 285 .

${ }^{111} I d$. at 285-86.

${ }^{112} \mathrm{Id}$. at 286. 
Considering breed registration standards as "rules of sport" and equating the actions of a breed registry to those of a sports league carries with it a number of implications for the antitrust analysis, some of which can be gleaned from the discussion in Section II. Although the implications likely pervade all facets of the antitrust analysis, this Article focuses on three: $(A)$ the establishment of an agreement or conspiracy and the single entity defense; (B) the definition of the product market and the distinction, if any, between sports and entertainment; and perhaps most significantly, (C) the application of the Rule of Reason and the latitude afforded by the courts to defendant organizations.

\section{A. The Establishment of an Agreement or Conspiracy and the Single Entity Defense}

In Copperweld Corp. v. Independence Tube Corp., the Supreme Court held that a parent corporation and its subsidiary are not capable of entering into a conspiracy for purposes of antitrust liability. ${ }^{113}$ Thus, as a matter of law, a single entity cannot violate Section 1 . Sports leagues often assert the single entity defense, arguing that the league is exempt from antitrust liability under Section 1 of the Sherman Act. As explained by Professor Feldman, sports leagues have "long viewed the single-entity defense as the antitrust 'holy grail,' because it shields them from attack under Section 1."114 Indeed, the single entity defense was asserted by the AQHA at the trial level and raised it again on appeal. As noted in Part I of this Article, the AQHA asserted the single entity defense based on its argument that because "there was no concerted agreement within the SBRC, but rather a mutual conclusion reached by individual members that the Rule should remain in place for the benefit of $\mathrm{AQHA}$, the decision was made by a single entity incapable of conspiring. ${ }^{115}$

Of course, the AQHA's single-entity defense failed in the district court. Indeed, the single-entity defense has succeeded only under limited

${ }^{113}$ Copperweld Corp. v. Independence Tube Corp., 467 U.S. 752 (1984).

114 Gabriel Feldman, The Puzzling Persistence of the Single-Entity Argument for Sports Leagues: American Needle and the Supreme Court's Opportunity to Reject a Flawed Defense, 2009 WISC. L. REV. 835, 837 (2009).

${ }^{115}$ Brief of Defendant-Appellant, supra note 4, at 11. 
circumstances, and the issue of whether a sports league can act as a single entity has been fraught with debate for the past half-century. ${ }^{116}$ Most recently, in American Needle v. NFL, the Supreme Court attempted to clarify this issue. ${ }^{117}$ Although the Supreme Court did not provide a simple, one-sentence rule, it made clear what it believed were indicators of concerted activity. According to the Court, the key factor is whether the entity represents "separate economic actors pursuing separate economic interests" so as to "deprive the marketplace of independent centers of decision-making." 118

American Needle concerned NFL teams which together agreed to grant an exclusive license to one company to produce all teams' fan apparel containing the teams' logos. The Court explained that each NFL team was an independently owned business, with a separate consciousness. ${ }^{119}$ Though these teams cooperate in some respects such as in the scheduling of games, they otherwise do not have common objectives when they compete with one another for fans, players, managers, coaches, and revenue. ${ }^{120}$ Further, these independently owned teams are potentially competing suppliers in the marketplace for intellectual property; thus, when conducting their licensing activities, the teams are not pursuing the interests of the NFL but their own individual interests. ${ }^{121}$ Such restraints by individual entities must be evaluated for Section 1 liability under the Rule of Reason.

The Court found that the reason for the teams' cooperation is not relevant to determining whether their actions are independent or concerted. ${ }^{122}$ Rather, what is important is whether that cooperation is essential for the teams to compete. ${ }^{123}$ While the scheduling of games is a concerted activity essential to competition, cooperation in the licensing and sale of apparel is not. ${ }^{124}$ Although the Court recognized that it "generally

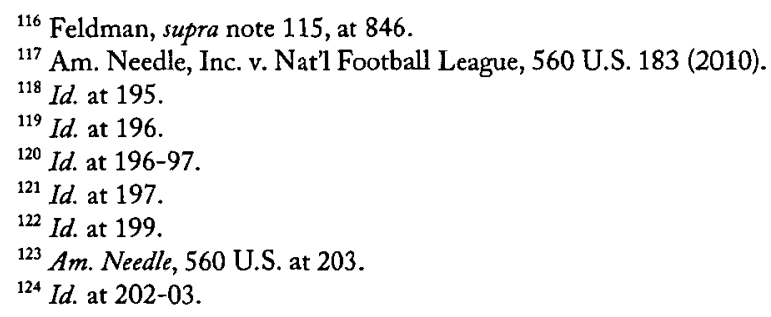


treat[s] agreement within a single firm as independent action on the presumption that the components of the firm will act to maximize the firm's profits," it also noted that in certain situations, such as that in American Needle, "agreements made within a firm can constitute concerted action ...."125 The Court emphasized that "separate economic actors" and "independent centers of decision making" help draw this distinction but declined to provide more precise guidance as to what combination of competitors would be treated as a single entity for purposes of Section 1 of the Sherman Act.

The Supreme Court's lack of guidance leaves lower courts with the difficult task of consistently differentiating between independent and concerted action. Lower courts will undoubtedly (continue to) struggle to define the boundaries of the entity at issue, particularly in the context of sports leagues, where the members of the league must necessarily cooperate with one another if there is to be the product of competition at all. This is significant for breed registries, in which the membership (individual breeders) must cooperate if they are to preserve the pedigree of the breed at issue. This cooperation includes defining what characteristics of the animal constitute the breed standard and engaging in competitive events to promote the breed standard. While one might argue that the exclusion of clones is not necessary to preserve the Quarter Horse-and in fact, this was an argument put forth by the plaintiffs in AQHA-that issue is not relevant for purposes of determining the applicability of the single entity defense. Pursuant to American Needle, what is critical is whether the cooperation is essential to create the product. ${ }^{126}$ For purposes of the single entity defense, the question is whether cooperation amongst individual breeders vis-à-vis the breed registry is necessary to preserve the breed of the Quarter Horse. If so, then defining the Quarter Horse to exclude clones is merely an incidental by-product of that cooperation, and the single-entity defense should exempt the breed registry from Section 1 scrutiny.

B. Defining the Product Market and the Distinction (if any) Between Sports and Entertainment

\footnotetext{
${ }^{125} \mathrm{Id}$. at 200.

${ }^{126}$ Am. Needle, 560 U.S. at 195.
} 
As noted earlier, the determination of the relevant product market is critical to establishing injury to competition. Anti-competitive effect decreases as the product market widens. On the other hand, anticompetitive effect increases as the product market narrows. When discussing sports leagues, a question often arises as to whether a particular sport competes within a broader entertainment market that includes not only other types of sport but other types of entertainment. If so, a restriction within a particular sport will have very little anticompetitive effect. In this respect, some commentators have asserted that most courts have defined the product market in sports cases much too narrowly. ${ }^{127}$

A minority of courts that have recognized a more expansive definition deserve brief mention. These courts recognize that sports and other forms of entertainment may be part of the same relevant market. For instance, in Theatre Party Associates, Inc. v. Scbubert Organization, ${ }^{128}$ the court suggested that "hit" Broadway shows do not constitute a separate submarket and questioned why the relevant market could not include the other forms of entertainment such as the opera or the ballet or even sports. ${ }^{129}$ Similarly, in his dissent of NFL $v$. Nortb American Soccer League, ${ }^{130}$ Justice Rehnquist noted that "NFL owners are joint venturers who product a product, professional football, which competes with other sports and other forms of

${ }^{127}$ See, e.g., Gary R. Roberts, Sports Leagues and the Sherman Act: The Use and Abuse of Section 1 to Regulate Restraints on Intraleague Rivalry, 32 UCLA L. REV. 219, 257 n. 135 (1984); Jerry Glick, Professional Sports Franchise Movements and The Sherman Act: When and Where Teams Should be Able to Move, 23 SanTA ClaRa L. REv. 55, 77-78 (1983).

${ }^{128}$ Theatre Party Assocs., Inc. v. Shubert Org., Inc., 695 F. Supp. 150 (S.D.N.Y. 1988).

${ }^{129}$ Id. at $154-55$. Perhaps significantly, the court states that the "fact that plaintiff chose to operate in a single market the most popular Broadway shows - does not make it a relevant market for antitrust purposes." Id. Likewise, plaintiffs in AQHA have chosen to operate in the Quarter Horse market. However, there exist other breed registries and performance associations that permit the registration and participation of clones. Such breed registries include the Studbook Zangersheide and the Anglo European Studbook. See Stallion Selection 2012: Zangersheide launches the selection season, ZANGERSHCEIDE, http://www.zangersheide.com/en/Stallion-Selection-2012 (last visited Sept. 17, 2014); Joris De Brabander: 'AES is trendsetter', ANGLO EUROPEAN STUDBOOK, (Sept. 16, 2013), http://angloeuropeanstudbook.co.uk/interviews/i2/joris-de-brabander-aes-is-trendsetter. Performance associations that welcome clones in their events include the National Barrel Horse Association, the National Cutting Horse Association, and Argentinian polo. See Facts about the NBHA, NAT'L BARREL HORSE ASSOC., http://www.barrelracers.com/nbha_facts.php (last visited Sept. 17, 2014); NCHA Says Clones Can Be Shown, QUARTER HORSE NEWS, http://www.quarterhorsenews.com/index.php/cutting/cutting-outside-the-pen/4296-ncha-says-clonescan-be-shown.html (last visited Sept. 17, 2014); Rory Carroll, Argentinian polo readies itself for attack of the clones, GUARDIAN (June 5, 2011), http://www.theguardian.com/world/2011/jun/05/argentinianpolo-clones-player\%.

${ }^{130}$ Hill v. United States, 459 U.S. 1074 (1982). 
entertainment in the entertainment market." ${ }^{131}$ In Windage, the court mentioned "entertainment dollars" when arguing that the effect of adopting irrational rules of sport would be to reduce that sport's audience. ${ }^{132}$ More recently, in its decision on American Needle, the Seventh Circuit recognized that the NFL competes with other forms of entertainment for a limited audience; "Simply put, nothing in $\S 1$ prohibits the NFL teams from cooperating so the league can compete against other entertainment providers." 133

These cases aside, courts have generally chosen more narrow definitions. This makes it more difficult for sports leagues' standards to pass antitrust muster, because when the relevant product market is defined to exclude both other sports and other forms of entertainment, then the market effects are multiplied. Nevertheless, Professor Lazaroff advocates that a more narrow approach is more consistent with both economics and antitrust precedent. ${ }^{134}$ Concentrating on the economic analysis, Lazaroff explains that sports fans do not respond to increases or decreases in ticket pricing in a way that suggests cross-elasticity of demand between one sport and another or between sports and other forms of entertainment. ${ }^{135} \mathrm{He}$ notes, “[m]any movie attendees may also enjoy watching sports, but it does not follow that a price increase in movie tickets would result in a significant shift of patronage to live sports events." ${ }^{136}$

The AQHA did not argue that the relevant product market expands beyond that of the Quarter Horse to include other equestrian breeds or even other forms of entertainment. It has not been established whether there is cross-elasticity of demand between one breed of horse and another or between horse breeding generally and other entertainment activities. This argument as to whether the Quarter Horse market should have been broadened to include other breeds or other forms of entertainment could

\footnotetext{
${ }^{131}$ Id. at 1077 (Rehnquist, J., dissenting).

${ }^{132}$ Windage, LLC v. U.S. Golf Ass'n, No. Civ. 07-4897, 2008 U.S. Dist. LEXIS 51065, at *11 (D. Minn. July 2, 2008).

${ }^{133}$ Am. Needle, Inc. v. Nat'l Football League, 538 F.3d 736, 744 (7th Cir. 2008), rev'd on other grounds, 557 U.S. 183 (2010).

${ }_{134}^{13}$ Daniel E. Lazaroff, Antitrust Analysis and Sports Leagues: Re-examining the Threshold Questions, 20 ARIZ. ST. L. J. 953, 979 (1988).

${ }^{135}$ Id. at $977-78$.

${ }^{136} \mathrm{Id}$. at 982.
} 
certainly be explored, although it is not within the scope of this Article to do so. What is more relevant to this Article is whether the Quarter Horse product market should have been narrowed to include a submarket for the "elite" American Quarter Horse, as asserted by the plaintiffs in $A Q H A$.

In Brown Shoe Co. v. United States, ${ }^{137}$ the Supreme Court introduced the concept of submarkets within markets:

The outer boundaries of a product market are determined by the reasonable interchangeability of use or the crosselasticity of demand between the product itself and substitutes for it. However, within this broad market, welldefined submarkets may exist which, in themselves, constitute markets for antitrust purposes. The boundaries of such a submarket may be determined by examining such practical indicia as industry or public recognition of the submarket as a separate economic entity, the product's peculiar characteristics and uses, unique production facilities, distinct customers, distinct prices, sensitivity to price changes, and specialized vendors. ${ }^{138}$

Lazaroff provides a good explanation of the potential submarkets existing for sporting equipment when he states:

Considering the fact that titanium golf clubs with graphite shafts often retail for several hundred dollars and many times the price of other clubs, one could reasonably contend that they constitute a relevant submarket separate from all other golf clubs. Similarly the cost and quality of

${ }^{137}$ Brown Shoe Co. v. United States, 370 U.S 294 (1962).

${ }^{138} I d$. at 322. 
the best aluminum baseball bats separate them from the lower cost, less powerful wooden models. ${ }^{139}$

Lazaroff goes on, however, to emphasize:

[D]ifferences in price and quality do not necessarily remove products from the market. Consumers may factor in the price and quality differentials when making a purchase and opt for either the high quality/higher price item or the lower quality/cheaper product. The products may still be competing for the consumers' dollars. At some point the differences in price and quality may suggest separate markets, but products need not be identical in price and quality to compete for the consumers' dollars. . . . the buying patterns of consumers should ultimately determine the relevant markets. ${ }^{140}$

Plaintiffs in $A Q H A$ submitted evidence that while demand for "nonelite" Quarter Horses is greatly dependent on price, demand for "elite" Quarter Horses is not price sensitive. ${ }^{141}$ Included within Plaintiffs' evidence was testimony from "one breeder that a five percent increase in price of an 'elite' Quarter Horse would not deter him from making a purchase” and that "he would rather buy two $\$ 100,000$ horses than twenty $\$ 10,000$ horses." ${ }^{142}$ It is questionable, however, whether the testimony of one breeder is indicative of the buying patterns of consumers of Quarter Horses as a whole or merely an indication of his personal preference. The AQHA's expert in valuing racehorses testified that his clients ultimately want to purchase a winning horse and that his job is to identify that horse. ${ }^{143} \mathrm{His}$ opinion was that the "best horse" is not synonymous with the most expensive horse and offered up examples of winners purchased for very low

${ }^{139}$ Daniel E. Lazaroff, Sports Equipment Standardization: An Antitrust Analysis, 34 GA. L. REV. 137,158 (1999).

${ }^{140}$ Id at $158-59$.

${ }^{141}$ Brief of the Plaintiffs-Appellees, supra note 41, at 35.

${ }^{142}$ Id. at 36.

${ }^{143}$ Brief of the Defendant-Appellant, supra note 4, at 25-26. 
prices. ${ }^{144}$ This is consistent with Lazaroff's explanation that products of different qualities and values may compete for the same consumers.

Of course, even accepting that there exists a submarket for the "elite" Quarter Horse, an issue remains as to whether the AQHA is dominated by this submarket's participants. This inquiry is important because it colors any analysis pursuant to the Rule of Reason, whereby the court must determine whether the restriction is reasonably related to achieving a legitimate goal. There was no dispute that only four members of the SBRC were owners and breeders of "elite" Quarter Horses, as defined by Plaintiffs. ${ }^{145}$ However, it was hotly contested whether those four members dominated the remaining members to the extent that the remaining members were unable to reach independent decisions on registering clones. ${ }^{146}$

\section{Applying the Rule of Reason with Deference}

Once the relevant markets are defined, courts typically apply the Rule of Reason-as opposed to per se scrutiny-to standards set by sports organizations. ${ }^{147}$ As a general matter, there are two approaches to analyzing Rule of Reason claims. The predominant approach was espoused in National Society of Professional Engineers v. United States, where the Court balanced the standard's anticompetitive effects with its procompetitive effects. ${ }^{148}$ Under this multi-factor approach, the plaintiff must first demonstrate that the prohibition at issue produces significant anticompetitive effects within the relevant product and geographic markets. The defendant must then establish a legitimate justification for the

${ }^{144} I d$.

${ }^{145} \mathrm{Id}$. at 12 .

${ }^{146}$ Brief of the Plaintiffs-Appellees, supra note 41, at 29-30.

${ }^{147}$ Per se analysis is appropriate where agreements and practices are so plainly anticompetitive and lack redeeming virtue that they can be presumed illegal without further examination. See Nat'l Soc'y of Profl Eng'rs v. United States, 435 U.S. 679, 692 (1978); N. Pac. R. Co. v. United States, 356 U.S. 1, 5 (1958); Broad. Music, Inc. v. Columbia Broad. Sys., Inc., 441 U.S. 1, 8 (1979); Hatley v. Am. Quarter Horse Ass'n, 552 F.2d 646, 652 (5th Cir. 1977) ("In an industry which necessarily requires some interdependence and cooperation, the per se rule should not be applied indiscriminately. In some sporting enterprises a few rules are essential to survival.").

${ }_{148}$ Nat'l Soc'y of Prof'1 Eng'rs v. United States, 435 U.S 679 (1978). 
prohibition and show that the prohibition has procompetitive effects. Justifications typically offered include the following:

(i) Restriction ensures product exists at all;

(ii) Restriction promotes competitive balance;

(iii) Restriction prevents free-riding; and

(iv) Restriction ensures economic efficiencies. ${ }^{149}$

As to the argument that the restriction ensures that the product exists at all, it is axiomatic to the purpose of the breed registry that it set forth parameters for breed conformities. At the broadest and most obvious level, no one can sensibly argue that the AQHA must register the foal of a Quarter Horse and donkey (i.e., a "mule") as a Quarter Horse or face antitrust scrutiny. Of course, such distinctions become much less obvious when discussing the registration of clones that genetically conform to the breed standard. ${ }^{150}$ Indeed, a cloned Quarter Horse is genetically indistinguishable from its non-cloned donor. Nonetheless, the method of conception (or manufacture) seems to beg a different question, and the reasoning of $\mathrm{McHugh}$ is instructive on this issue. There, the court accepted that natural cover defined Thoroughbred breeding and racing-that the method of conception went to the "heart of the sport." ${ }^{151}$ McHugh acknowledges that what defines the breed standard of a Thoroughbred is not only its genetic markers but also the method by which it was conceived. Of course, it may be more difficult for a breed registry such as the AQHA, which allows the registration of foals born of artificial insemination and embryo transfer, to argue that the method of conception defines the Quarter Horse. This may be a better argument left for breed registries such

149 James T. McKeown, The Economics of Competitive Balance: Sports Antitrust Claims After American Needle, 21 MARQ. SPORTS L. REV. 518, 530 (2011); see also Nat'l Collegiate Athletics Ass'n v. Bd. of Regents, 468 U.S. 85, 101 (1984) (recognizing that in certain industries "horizontal restraints on competition are essential if the product is to be available at all"); Major League Baseball Props., Inc. v. Salvino, Inc., 542 F.3d 290 (2d Cir. 2008).

${ }^{150}$ Brief of Plaintiffs-Appellees, supra note 41, at 48 (Plaintiffs in AQHA repeated that the donor horse and its clone were merely "twins separated in time.").

${ }^{151}$ McHugh v Australian Jockey Club Ltd. (No. 13) [2012] FCA 1441, 1463 (Austl.), available at http://www.austlii.edu.au/au/cases/cth/FCA/2012/1441.html. 
as the Jockey Club, which has consistently required natural cover as a condition precedent to registration.

As to competitive balance being a procompetitive justification, courts have explained that this concept reflects "the expected equality of opportunity to compete and prevail on the field. Competitive balance also relates to the fans' expectations that each team is a potential champion i.e., that each Club has a reasonable opportunity to win each game and also compete for a championship." 152 In the context of equestrian breed registries and their related competitions, competitive balance may be maintained through genetic diversity. Proponents of cloning may assert that SCNT allows the introduction of DNA into the gene pool that otherwise would not be available, such as those of a gelded horse. The fear, of course, is that while cloning may introduce otherwise unavailable DNA, that DNA will be only that of super "winners," creating a field of Secretariats and Man O'Wars in Thoroughbred racing. Undoubtedly, a large part of what makes Thoroughbred racing exciting is the field variety and that on any given day, an underdog could win.

Free riding exists where one is able to benefit disproportionately from the efforts of others, which may lead to inefficiencies in the market if investors are no longer incentivized to promote and develop the product. ${ }^{153}$ Breeders spend considerable sums in developing a winner, whether that is through choosing the right mating combination of broodmare and stud horse, training the resulting foal, or both. If one can simply have a winner by cloning a previous winner, investments that have been made in traditional breeding and training methods are made worthless. Indeed, can it be said that the "breeder" choosing to clone a winner is doing anything other than free riding on the investments made by previous breeders?

As to assurance of economic efficiencies, antitrust laws aim to maximize consumer welfare through the economic efficiency of markets by preventing limits on competition. ${ }^{154}$ Restraints, however, are not always

${ }^{152}$ Salvino, 542 F.3d at 333.

${ }^{153}$ See id. at 340.

${ }^{154}$ RoBert H. Bork, The ANTITRUST PARAdOX: A POLICY AT WAR WITH ITSELF 405-06 (Basic Books, 1978). Judge Richard Posner agrees that "[a]lmost everyone professionally involved in antitrust today - whether as litigator, prosecutor, judge, academic, or informed observer . . . . agrees that the only goal of the antitrust laws should be to promote economic welfare, ...." and by "economic 
anticompetitive, and in certain situations restraints can increase economic efficiency and render markets more competitive. ${ }^{155}$ As previously discussed and recognized by the Supreme Court, sometimes restraints are necessary for the product to exist at all. ${ }^{156}$ This concept of increased efficiency is likely what the $M c H u g h$ court was driving at when it found that because the rules prohibiting registration of foals bred by artificial insemination contribute to the interests of those who participate in the sport, "there would be reduced competition" without such rules. ${ }^{157}$ Arguably, it is the choices made by consumers-not courts-that determine what constitutes an efficient market. If participants in the Quarter Horse market have decided that they prefer non-cloned Quarter Horses, then the restriction at issue ensures that the efficiencies of that market are maintained.

Continuing in the typical application of the Rule of Reason, once the defendant establishes the restriction's pro-competitive benefits, the plaintiff must show that the restriction is not reasonably necessary to achieve the stated objective or that the anticompetitive effects outweigh the procompetitive effects. ${ }^{158}$ Typically, in cases involving rules of sport, the objective of the governing body is either to define and preserve the game or to ensure the health and safety of its participants. In the context of a breed registry, registration rules will likely be for the purpose of defining and promoting the breed and associated competition. Thus, as the court did in $M c H u g h$, in weighing the relative merits of the anticompetitive and procompetitive effects, a court must consider; (i) whether the prohibition is an attribute of and helps a registry's objective of defining the breed; and (ii) whether in answering this question the breed registry should be afforded some deference. Often, in cases involving antitrust challenges to "rules of sport" and sports leagues, courts provide the governing body with some

welfare," Judge Posner means "the economist's concept of efficiency." RICHARD A. POSNER, ANTTTRUST LAW ix ( $2 \mathrm{~d}$ ed. 2001). There is, however, some disagreement among academics as to whether the promotion of economic efficiency is a goal of antitrust laws. See, e.g., John B. Kirkwood \& Robert H. Lande, The Fundamental Goal of Antitrust: Protecting Consumers, Not Increasing Efficiency, 84 NOTRE DAME L. REV. 191, 192 (2008).

155 Broad. Music, Inc. v. Columbia Broad. Sys., Inc., 441 U.S. 1, $23-24$ (1979).

${ }^{156}$ Nat'l Collegiate Athletic Ass'n v. Bd. of Regents, 468 U.S. 85, 101 (1984).

${ }_{157}$ McHugh v Australian Jockey Club Ltd. (No. 13)[2012] FCA 1441, 1464 (Austl.), available at http://www.austlii.edu.au/au/cases/cth/FCA2012/1441.html.

${ }^{158}$ Nat'l Soc'y of Profl Eng'rs v. United States, 435 U.S 679, 688-89 (1978). 
deference under the law. ${ }^{159}$ Deference to the governing body seems appropriate, given that it is the governing body which will know how to best preserve the game for the prosperit, of its participants and enjoyment of its spectators.

Yet in that vein, one can see that the "balancing approach" of National Society of Engineers may hinge disproportionality on whether the court accepts the importance of preserving the game. In response to this concern, an alternative multi-factor approach was set forth in Gunter Harz, in which the courts asks:

(1) Is the standard intended to accomplish a goal consistent with the policy justifying self-regulation;

(2) Is the action reasonably related to that goal;

(3) Is the standard no more extensive than necessary; and

(4) Has the association provided procedural safeguards, which assure that the restraint is not arbitrary and which furnish a basis for judicial review?

The existence of this alternative approach is discussed at length by one commenter who notes that under these factors, rules of sport will be upheld "so long as they further the organization's goals and are not applied in a discriminatory, arbitrary or capricious manner." ${ }^{161}$ The authors of this Article, however, do not believe that Gunter Harz is significantly inconsistent with the balancing approach of National Society of Engineers. It appears that the first factor of Gunter Harz merely substitutes as a presumption of pro-competitive benefit. Put another way, if the standard is intended to accomplish a goal consistent with the policy justifying selfregulation, then that goal is pro-competitive. This certainly solves any quandary of attempting to establish any economically-based pro-

${ }^{159}$ See, e.g., Race Tires of Am., Inc. ข. Hoosier Racing Tire Corp., 614 F.3d 57, 83 (3d Cir. 2010) (applying deference to the defendant's rules and upholding them without consideration of less restrictive alternatives as there was "good faith, more than sufficient" pro-competitive justification for the restraint). Professor Gabe Feldman explains that that "[a]lthough sports leagues have not been granted blanket antitrust immunity, courts have afforded them ... deference under the law." Gabe Feldmen, $A$ Modest Proposal for Taming the Antitrust Beast, 41 PEPP. L. REV. 249, 249 (2013).

${ }^{160}$ Gunter Harz, 511 F.Supp. at 1116.

161 See Schlomi Feiner, Regulation of Playing Equipment by Sports Associations: The Antitrust Implications, 10 U. MIAMI BUS. L. REV. 585, 615 (2002). 
competitive benefits by recognizing that for a voluntary, self-regulatory organization, self-regulation and the goals related to self-regulation are themselves pro-competitive. Meanwhile, the second and third factors of Gunter Harz appear to ask the same question as the third factor of the balancing approach-that is, whether the restriction is reasonably necessary to achieve the stated objective.

The only factor that truly distinguishes Gunter Harz is the "due process" concern. Procedural safeguards undoubtedly refer to some sort of opportunity for "notice and comment," and presumably organizations that have failed to provide such safeguards might not be afforded as much latitude by the court when it determines the legitimacy of the restriction at issue. Nonetheless, under this approach, most non-arbitrary "rules of sport" would survive Rule of Reason scrutiny. As explained by one court:

A membership organization ... as a voluntary organization or one of a social nature of sports organization must be left to legislate its own rules and its own guidelines for participation of its members for the purposes for which it was created so long as that legislation is not done in an unreasonable manner and without malice or intention to harm a single member or segment of membership. Such membership organizations have the right to adopt such rules to protect their very existence. ${ }^{162}$

\section{Applicability of the Quick Look Doctrine}

A full Rule of Reason analysis (whether under the balancing or alternative approach) may not be needed if the defendant can successfully assert that that the Quick Look Doctrine applies. Courts can use the "quick look" to bypass full Rule of Reason analysis. In Texaco v. Dagher, the Supreme Court first introduced the Quick Look Doctrine. ${ }^{163}$ Without conducting a full Rule of Reason analysis, the Court concluded that the

\footnotetext{
${ }^{162}$ STP Corp. v. U.S. Auto Club, Inc., 286 F.Supp. 146, 151 (S.D. Ind. 1968)

${ }^{163}$ Texaco Inc. v. Dagher, 547 U.S. 1 (2006).
} 
practice at issue was "core" to the business itself. ${ }^{164}$ The Court explained that a practice might be "ancillary to the legitimate and competitive purposes of the business association, and thus valid." 165 These words echo a common law approach known as the ancillary restraint doctrine, under which courts take into account the uniqueness of some businesses. ${ }^{166}$ Indeed, the Quick Look Doctrine was again mentioned by the Supreme Court in American Needle, when it explained that "[when] 'restraints on competition are essential if the product is to be available at all' . . the Rule of Reason may not require a detailed analysis; 'it can sometimes be applied in the twinkling of an eye."'167

Following American Needle, a number of cases involving sports leagues have used the Quick Look Doctrine to bypass a full Rule of Reason analysis. For instance, in Agnew v. NCAA, the Seventh Circuit agreed that it had a license to find some rules to be pro-competitive and thus the Rule of Reason could be applied "in the twinkling of an eye." 168 In Rock $v$. $N C A A$, the Southern District of Indiana provided the NCAA ample latitude when it determined that the NCAA's prohibition concerning athletics-based aid maintains the tradition of amateurism in college sports and thus the prohibition was presumptively pro-competitive "in the twinkling of an eye." 169 Similarly, in Washington v. NFL, the District of Minnesota found that "the Rule of Reason compels the conclusion that, even if there is concerted action to restrain trade in Plaintiffs' images, that agreement 'is necessary to market the product at all' and is therefore not illegal." ${ }^{170}$

\section{${ }^{164} \mathrm{Id}$. at 7. \\ ${ }^{165} \mathrm{Id}$.}

${ }^{166}$ Under this approach, "[i]f the restraint is merely ancillary to some other legitimate business purpose and is not intended to either harm the market or the field of competition, the court can then feel satisfied that the restraint is merely a function of a unique business arrangement where certain practices are recognized as harmless to the workings of a free market economy." See Thane Rosenbaum, Antitrust Implications of Professional Sports Leagues Revisited: Emerging Trends in the Modern Era, $41 \mathrm{U}$. MIAMI L. REV. 729, 738 (1987). The ancillary restraint doctrine accounts for the needs of a particular industry. Thus, under this approach, standards on registration could be justified on the association's need to maintain competitive aspects of the sport.

${ }^{167}$ Am. Needle, Inc. v. Nat'l Football League, 560 U.S. 183, 203 (2010).

${ }^{168}$ Agnew v. Nat'l Collegiate Athletic Ass'n, 683 F.3d 328, 341 (7th Cir. 2012).

${ }^{169}$ Rock v. Nat'l Collegiate Athletic Ass'n, 928 F. Supp. 2d 1010, 1026 (S.D. Ind. 2013).

${ }^{170}$ Washington v. Nat'l Football League, 880 F. Supp. 2d 1004, 1007 (D. Minn. 2012). 


\section{IMPLICATIONS OF ALLOWING ANTITRUST SUITS TO REDEFINE}

\section{A SPORT: DEVALUATION OF THE SPORT}

Arguably, the ultimate product produced by a breed registry is entertainment by staging competitions that are consumed by their participants and spectators. Thus, the governing body of the breed registry has an economic incentive to establish rules that maximize the value of its breed and the breed's associated competitive activities. Rules and standards set forth by the governing body affect the value of that competition by defining the breed and adding excitement to its associated activities. Perhaps the greatest fear is that in the area of equestrian competition where the end goal is to produce a winner, cloning will only incentivize breeders to produce more of the same previous winners. Is a field proliferated with the "same" winners more entertaining? Is watching ten California Chromes race against each other more exciting?

This is, of course, difficult to determine ex ante, but it would certainly change the experience of Thoroughbred racing from the perspectives of both the participants and the spectators.

The typical allegations involving restrictions on registration based on reproductive technique are anticompetitive include arguments that the reproductive technique at issue would make it cheaper for breeders to breed. For instance, the plaintiffs in $A Q H A$ argued that cloning will expand the supply of "elite" Quarter Horses and that increased supply would decrease price and thereby eliminate barriers to entry to the breeding market. ${ }^{171}$ The policy behind antitrust law is to promote the economic welfare of consumers, not the competing breeder-manufacturers, though to a certain extent they are one and the same here. ${ }^{172}$ Nonetheless, it remains not entirely clear how the plaintiffs in $A Q H A$ demonstrated that consumers were injured, whether those consumers are the breeder-manufacturers of

171 Brief of the Plaintiffs-Appellees, supra note 41 , at $43-44$. Whether cloning will actually increase supply is highly questionable. Cloning is an expensive venture, costing approximately $\$ 150,000$ per attempt, with a low success rate. As noted in Part I, only a very low percentage of clones survive.

172 Brunswick Corp. v. Pueblo Bowl-O-Mat, Inc., 429 U.S. 477 (1977) (holding that antitrust laws protect consumers, not competitors); The Antitrust Laws, FEDERAL TRADE COMM'N, http://www.ftc.gov/tips-advice/competition-guidance/guide-antitrust-laws/antitrust-laws (last visited Oct. 16, 2014) ("Yet for over 100 years, the antitrust laws have had the same basic objective, to protect the process of competition for the benefit of consumers ...."). 
Quarter Horses or mere participants and spectators at Quarter Horse competitions. Typically, consumer welfare is maximized through antitrust laws by ensuring the existence of higher quality products, lower prices, greater choice, and greater innovation. ${ }^{173}$

How quality is defined in the equestrian breeding and competition market is questionable and is perhaps central to the issue. Many consumers may consider cloned horses to be of lesser quality than naturally bred horses, even though they are genetically identical. A good comparison is that of synthetic diamonds to natural diamonds. Today, synthetic diamonds are virtually indistinguishable from natural diamonds. ${ }^{174}$ Nevertheless, jewelry consumers stronger prefer the latter-which take 3 billion years to create-over the former-which take 3 weeks. ${ }^{175}$ Perhaps the reason for this preference is that for certain products the value in owning the product is not only in the physical "thing" but also in the process by which that "thing" was created. One can draw from the diamond analogy again when we see that the availability of synthetic diamonds have not decreased the price of natural diamonds. ${ }^{176}$ In fact, even with the proliferation of synthetic diamonds, the price of natural diamonds has steadily increased. ${ }^{177}$

As to greater choice, cloning may introduce otherwise unavailable genes into the pool, but again, one questions whether this hypothesis will prove to be true if, as the $A Q H A$ plaintiffs assert, cloning would be used to manipulate and isolate certain "desirable" genetic attributes. ${ }^{178}$

${ }^{173} \mathrm{Id}$.

${ }^{174}$ Lab-Created Diamond FAQ, GEMESIS, http://gemesis.com/education/faqs/ (last visited Sept. 18,2014 ) (explaining that both lab-created and natural diamonds "have the same physical, chemical and optical properties and emerge as rough diamonds .... [b]oth are, in fact, diamond").

${ }^{175}$ Elizabeth F. Purinton, Does Artificial Diamond Equate Artificial Love?: Consumers'Attitudes, 19

AM. SOC'Y BUS \& BEHAV. SCI. PROC. 1 (2012), available at http://asbbs.org/files/ASBBS2012V1/PDF/P/PurintonE.pdf; Elsa Wenzel, Synthetic diamonds still a rough cut, CNET NEWS, (Feb. 14, 2007), http://news.cnet.com/Synthetic-diamonds-still-a-roughcut/2100-11395_3-6159542.html.

${ }_{176}$ Chloe $\mathrm{Wu}$, The Impact of Synthetic Diamonds on the Natural Diamond Industry, EUROMONITOR INT'L (July 9, 2014), http://blog.euromonitor.com/2014/07/the-impact-of-syntheticdiamonds-on-the-natural-diamond-industry.html (explaining that natural stones "continue to command a premium over their synthetic counterparts").

177 Yury Spektorov, Olya Linde \& Pierre-Laurent Wetli, The Global Diamond Industry: Portrait of Growth, BAIN \& CO. (Dec. 12, 2012), http://www.bain.com/publications/articles/global-diamondindustry-portrait-of-growth.aspx.

${ }^{178}$ Brief of the Plaintiffs-Appellees, supra note 41, at 47. 
With respect to greater innovation, is this type of innovation desirable? In $A Q H A$, Abraham and Veneklasen suggest that the ability to isolate genetics is a positive attribute of cloning. While cloning could arguably be used the increase genetic diversity, will this be the most likely outcome? Alternatively, as the AQHA fears, will cloning be used to create a Quarter Horse population that has substantially less genetic diversity? One can see the perverse effects of isolating attributes in certain canine breeds, whose features have become grossly distorted due to "unnatural" selection. ${ }^{179}$ Indeed, some breeds such as the English Bulldog are facing serious health issues because they have been bred to conform to arbitrary standards of desirability. ${ }^{180}$ Is it an antitrust violation for a breed registry charged with improving the breed to adopt rules designed to avoid such results?

Of course, we must also query whether a breed registry can be presumed to be maximizing the value of the sport through its registration standards. The governing body of a breed registry is often comprised of breeders who have an economic interest in the sale of the input. Thus, those in charge may have an economic incentive to adopt inefficient standards and not maximize the value of the sport. However, by itself, an economic interest in the sale of the input is not sufficient to produce anticompetitive effect. ${ }^{181}$ Breeders who participate in the governance of the breed registry will injure themselves economically if because of their stake in the input they insist on creating an inferior, less desirable product. ${ }^{182}$ If breeders insist on the inferior product, then the market will provide the necessary sanction; ${ }^{183}$ antitrust sanctions are unnecessary and possibly anticompetitive.

Indeed, when "rules of sport" are altered through antitrust scrutiny, adverse implications arise. Two implications of particular concern to breed registries are the impairment of long-term competition and the reduction in skills required to participate in the sport. Long-term competition is impaired because the alteration of a "rule of sport" undercuts the value of

179 See Lindsay Pollard-Post, Why Is HBO's 'Real Sports' Calling Foul on Dog Breeding?, PETA (Apr. 26, 2014), http://www.peta.org/blog/hbo-real-sports-dog-breeding/.

\footnotetext{
${ }^{180} \mathrm{Id}$.

${ }^{181}$ Lopatka, supra note 82, at 29.

${ }^{182}$ See id.

${ }^{183} \mathrm{Id}$.
} 
competition between current and former participants. The conception of long-term competition is useful in understanding that the rule-making body is trying to preserve the integrity, traditions, and character of the sport. Take, for instance, cases where the rule at issue prohibits the use of newly developed equipment, which would otherwise provide players with a competitive advantage. ${ }^{184}$ The governing bodies in these cases resisted innovations that would arguably change the way the game is played. ${ }^{185}$ What is any different in equestrian competitions, such as Thoroughbred racing, where fielding multiples of the same horse would forever change how trainers, jockeys, and spectators engage in the sport?

Exploration of the human capacity is also impaired and the skills required of human participants in the sport are reduced when "rules of sport" are changed arbitrarily. Value is derived from competing against the limits of nature. In breeding horses, the limits of nature are clearly being manipulated when assisted reproductive techniques are used, whether those techniques are artificial insemination or cloning. Rules that prohibit assisted reproductive techniques attempt to establish boundaries for breeding winners unmodified by technological advances that permit the manipulation of genetics. The concept of nature also supports another, related value of equine sport-the skill to ride or train a winner. These skillsets correlate with the genetic diversity of the candidate pool. Arguably, the less diverse the pool, the fewer skills required to be a successful rider or trainer.

Undoubtedly, self-regulating breed registries must set rules in order to meet their purpose of defining and promoting the breed through registration and associated competitive activities. Courts should provide deference to the registries setting such rules, because these are "rules of sport." Indeed, failing to do so may produce some of the foregoing perverse effects, which are antithetical to antitrust policy. Moreover, breed registries, such as the AQHA, are essential to maintaining the breed. Continued antitrust litigation may intimidate and deter breed registries from

${ }^{184}$ See Gunter Harz, 511 F. Supp. 1103 (upholding the USTA's rule prohibiting the use of double-strung tennis racquets allowing players to give more spin to the ball); see also Weight-Rite Golf $\mathbf{v}$. U.S. Golf Ass'n, 766 F.Supp. 1104 (M.D. Fla. 1991) (upholding the USGA's rule prohibiting the use of a golf shoe that assisted golfers in distributing their weight in a manner that assisted with their swing).

${ }^{185}$ See Gunter Harz Sports, 511 F. Supp. 1103; see also Weigbt-Rite Golf, 766 F. Supp. 1104. 

KY. J. EQUINE, AGRIC., \& NAT. RESOURCES L. [Vol. 7 No. 1

organizing or continuing to operate. So long as the registry is establishing rules reasonably connected to its purpose, courts should refrain from applying antitrust sanctions. 